\title{
Role of interfering substances in the survival of coronaviruses on surfaces and their
} impact on the efficiency of hand and surface disinfection

Szpiro L ${ }^{1 \#}$, Pizzorno $A^{2 \#}$, Durimel L ${ }^{1}$, Julien $\mathrm{T}^{2,3}$, Traversier $\mathrm{A}^{2}$, Bouchami $\mathrm{D}^{1}$, Marie $\mathrm{Y}^{1}$, Rosa-Calatrava $\mathrm{M}^{2,3 \&}$, Terrier $\mathrm{O}^{2 \&}$ and Moules $\mathrm{V}^{1 \& *}$

${ }^{1}$ : VirHealth SAS, Domaine La Buire Laennec, 7-11 rue G. Paradin, 69008 Lyon, FRANCE

2 : CIRI, Centre International de Recherche en Infectiologie, (Team VirPath), Univ Lyon, Inserm, U1111, Université Claude Bernard Lyon 1, CNRS, UMR5308, ENS de Lyon, F69007, Lyon, France

3. VirNext, Faculté de Médecine RTH Laennec, Université Claude Bernard Lyon 1, Université de Lyon, Lyon, France.

\# These authors contributed equally

\& These authors contributed equally

* Corresponding author: v.moules@ virhealth.fr

\section{Abbreviations}

RH: relative humidity

Declarations of interest: LS, LD, DB, YM and VM are employees of VirHealth SAS. Other authors declare no conflict of interest. 


\begin{abstract}
Contaminated environmental surfaces are considered to represent a significant vector for hospitalacquired viral infections. In this study, we have evaluated the impact of interfering substances on SARS-CoV-2 surface stability and virucidal efficiency of hand sanitizers and surface disinfectant. To this end, surface stability of SARS-CoV-2 was measured on stainless steel in different experimental conditions, with or without an artificial mucus/saliva mixture and compared against that of human coronavirus HCoV-229E and feline coronavirus FCoV. The impact of the mucus/saliva mixture on the virucidal efficiency of 3 commercial alcohol hand sanitizers and 1 surface chemical disinfectant against SARS-CoV-2, HCoV-229E and FCoV was then measured. Our results indicate that mucus/saliva mixture did not demonstrate a beneficial effect on the surface survival of tested viruses, with temperature being an important parameter. In addition, we demonstrated that interfering substances may play an important role in the virucidal efficacy of hand sanitizers and disinfectants, highlighting the need for adapted testing protocols that better reflect current "real life" conditions of use.
\end{abstract}

Keywords: SARS-CoV-2; coronavirus; virus stability; virucidal activity 
medRxiv preprint doi: https://doi.org/10.1101/2020.08.22.20180042; this version posted August 25, 2020. The copyright holder for this preprint (which was not certified by peer review) is the author/funder, who has granted medRxiv a license to display the preprint in perpetuity.

All rights reserved. No reuse allowed without permission.

\section{Highlights}

- Contaminated environmental surfaces are a significant vector for viral infections.

- We studied the impact of interfering substances on SARS-CoV-2 surface stability and virucidal efficiency.

- Mucus/saliva did not demonstrate a beneficial effect on viral surface stability, with temperature being an important parameter.

- Interfering substances are important for virucidal surface activity of disinfectants. 
medRxiv preprint doi: https://doi.org/10.1101/2020.08.22.20180042; this version posted August 25, 2020. The copyright holder for this preprint (which was not certified by peer review) is the author/funder, who has granted medRxiv a license to display the preprint in perpetuity.

All rights reserved. No reuse allowed without permission.

\section{Introduction}

Respiratory diseases caused by human coronavirus infection are of both medical and socio-economic importance. Severe acute respiratory syndrome coronavirus (SARS-CoV), Middle East respiratory syndrome coronavirus (MERS-CoV) and currently SARS-CoV-2 have crossed the species barrier and entered the human population to cause severe disease. As observed for a large number of respiratory viruses, airborne transmission and fomite transmission are thought to play important roles in the epidemiology of these viruses (1). Several reviews and models have suggested that indirect contact transmission involving contaminated surfaces could be the predominant transmission route for certain respiratory viruses, including influenza, in some settings (2-4). Indeed, contaminated environmental surfaces are considered to represent a significant vector for hospital-acquired viral infections $(5,6)$.

Surface contamination by respiratory viruses may occur by direct landing of droplets expelled during the coughing or sneezing of an infected individual or as a result of indirect transfer from their hands contaminated with excreted virus. During the 2002-2003 SARS epidemic, the detection of virus on a variety of surfaces and objects in healthcare settings provided evidence of fomites playing an important role in viral dissemination (7). Boone and Gerba (2) demonstrated the presence of influenza virus on $50 \%$ of fomites found in homes and daycare centers during an active influenza season. Influenza A virus has also been shown to be transferred from stainless steel countertops to hands up to $24 \mathrm{~h}$ after surface contamination (8). The transfer of human parainfluenza virus and rhinovirus from contaminated surface to clean fingers supports a role for fomites in the contamination of hands with both viruses (9).

For any environmental contamination to be relevant, a virus should not only remain infectious on the recipient surface but also persist at a sufficient concentration to enable it to reach the respiratory tract via finger contamination. In general terms, the potential of a fomite to spread a given infectious agent is directly related to the capacity of the agent to survive on that surface. The surface stability of viruses is generally influenced by the type of surface, environmental factors such as relative humidity (RH) and temperature, and the presence of body fluid secretions.

Coronaviruses have the capacity to survive on a wide range of porous and non-porous materials (10).

A recent study has shown that SARS-CoV and SARS-CoV-2, at $40 \% \mathrm{RH}$ and $21-23{ }^{\circ} \mathrm{C}$, were most 
stable on smooth surfaces and that viable virus could be detected up to 3 and 4 days respectively post application (10). Chin et al showed that SARS-CoV-2 could be detected on contaminated stainless steel supports, at $65 \% \mathrm{RH}$ and $22{ }^{\circ} \mathrm{C}$, seven days after experimental inoculation (11). SARS-CoV has been reported to stay viable for up to five days at 22 to $25^{\circ} \mathrm{C}$ and 40 to $50 \% \mathrm{RH}$, with an increase in temperature and humidity resulting in a rapid loss of viability (10). Casanova et al demonstrated a higher stability in SARS-CoV compared to the human coronavirus HCoV-229E, which in a dried state retained residual infectivity even after 6 days compared to the loss of infectivity within 3 days observed in HCoV-229E (12). MERS-CoV virus could still be recovered on stainless steel after 2 days in the $20{ }^{\circ} \mathrm{C}$ and $40 \% \mathrm{RH}$ condition, whereas it remained viable for a much shorter $8 \mathrm{~h}$ at $30{ }^{\circ} \mathrm{C}$ and $80 \% \mathrm{RH}$, and 24 hours at $30{ }^{\circ} \mathrm{C}$ and $30 \% \mathrm{RH}$ (13). All studies that have tested varying temperature and $\mathrm{RH}$ agree that lower temperatures and higher $\mathrm{RHs}$ systematically favor the survival of coronaviruses $(13,14)$.

During and after illness, viruses are shed in large numbers in body secretions, including blood, feces, urine, saliva, and nasal fluid, all of which comprise high levels of protein and other biological organic matter. While several studies appear to have reached a consensus agreement on the role of both fecal material and blood in the increased stability of viruses on environmental surface (15-17), the potential beneficial effect of respiratory secretions on surface viral survival remains unclear. Mixing of highly concentrated inocula with respiratory mucus increased the infectiousness of influenza viruses, allowing its transmission for up to 17 days (18) and thus confirming the protective role of human mucus for the survival of respiratory viruses previously shown by Parker et al (19). However, human rhinovirus type 14 suspended in tryptose phosphate broth could survive for more than $20 \mathrm{~h}$ incubation, though for less time when suspended in bovine mucin or in nasal secretions (20).

No data are available concerning the transmissibility of coronaviruses from contaminated surfaces to hands. Data are however available concerning other respiratory viruses including influenza A virus, parainfluenza virus 3 and rhinovirus which were shown to be transferred to the hands (1.5 to $31.6 \%$ of the viral load) after a contact of $5 \mathrm{~s}$ with an inoculated surface $(24,9)$. Several studies have found that frequent hand-surface contact can lead to rapid diffusion of surface contamination $(25,26)$. In view of the indirect transmissibility of viruses, compliance with both hand hygiene and surface disinfection 
recommendations is critical to reducing colonization and infection of the hands of entire populations but in particular the hands of health-care workers.

An important consideration in the strict compliance of these recommendations is the finding in several studies that interfering substances (including body secretions) could have a strong impact on the efficiency of a disinfectant $(27,28)$. To simulate clean/dirty environments, standardized interfering substances are used to evaluate disinfection product efficiency according to Phase $2 \mathrm{EN}$ standards. While the determination of surface virucidal efficiency of a disinfectant is managed according to EN16777 standards through the use of inoculated stainless steel carriers, the virucidal efficiency of hand rub products is currently tested using the EN14476 suspension test $(29,30)$. The efficiency of hand rub products is based upon a titer reduction of $\geq 4 \log 10$ in a maximum contact time of $30 \mathrm{~s}$ to 60 $\mathrm{s}$ in compliance with suspension test standards.

In an attempt to better understand and thus better control the transmission of SARS-CoV-2 behind the recent and ongoing pandemic, the impact of body fluid secretions, from coughing or sneezing corresponding to an artificial mixture containing nasal mucus and saliva, on the surface stability of SARS-CoV-2 and the virucidal efficiency of disinfectant were tested. To this end, surface stability was measured on stainless steel at 7 and $25{ }^{\circ} \mathrm{C}(65 \% \mathrm{RH})$ with or without the artificial mucus/saliva mixture and compared against that of human coronavirus $\mathrm{HCoV}-229 \mathrm{E}$ and the standardized feline coronavirus FCoV strain used in EN standard tests of surface virucidal activity (23). The impact of the mucus/saliva mixture on the virucidal efficiency of 3 commercial alcohol hand sanitizers (according to the EN14476 standard suspension test) and 1 surface chemical disinfectant (according to the virucidal surface quantitative EN16777 test) against SARS-CoV-2, HCoV-229E and FCoV was then measured.

\section{Methods}

Viruses and cell lines. The HCoV-229E coronavirus (ATCC-VR-740), the SARS-CoV-2 (BetaCoV/France/IDF0571/2020) and the feline coronavirus (FCoV, RVB-1259) were chosen for this study. HCoV-229E, SARS-CoV-2 and FCoV were produced on MRC5 cells (ATCC-CCL-171), on Vero E6 cells (ATCC- CCL-1586) and on CRFK cells (CCLV-RIE-115), respectively. For the 
evaluation of surface disinfectant, another enveloped virus was introduced, the modified vaccinia virus Ankara (MVA, ATCC VR-1566), produced on BHK-21 cells (ATCC CCL-10). Cells were cultivated in DMEM (1 or $4.5 \mathrm{~g} / \mathrm{l}$ of glucose) or EMEM medium with L-glutamine and antibiotics, with or without FCS.

Virus stability. The stability was evaluated on functionalized stainless steel disks. Disks were washed in $95 \%$ Decon then rinsed with distilled water and immersed in $70 \%$ ethanol before autoclaving 10 min at $121^{\circ} \mathrm{C}$. Virus stability on stainless steel disks was determined by the recovery of virus previously deposited on surface. The inoculum was made by following the NF EN 16777 standard. 50 $\mu \mathrm{L}$ of purified virus or virus mix with artificial saliva (ASTM 2721, Table 1) and epithelium mucus was put in the center of a stainless-steel disk. The deposit was dried under PSM for a maximum of $1 \mathrm{~h}$. Disks were then placed in a refrigerator at $7{ }^{\circ} \mathrm{C}$ or in an oven stabilized at $25{ }^{\circ} \mathrm{C}$ and $65 \%$ relative humidity for different lengths of time (from 0 to $96 \mathrm{~h}$ ). The recovery of each virus at different time points was performed using the same protocol: $2 \mathrm{ml}$ of infection medium was first placed on the disk and incubated for $3 \mathrm{~min}$ at room temperature. All the liquid was collected into a tube and quantified by TCID50/ml (Spearman and Karber method). The quantification limit was determined taking into account the cytotoxicity. The limit of detection (LOD) on every cell, was $0.5 \log 10$ TCID50/support.

Virucidal activity according to suspension test. The virucidal activity of three commercial hand rub products against SARS-CoV-2, $\mathrm{HCoV}-229 \mathrm{E}$ and $\mathrm{FCoV}$ was determined using the quantitative suspension test according to EN 14476, comparing standardized interfering substance (clean condition, $0.3 \mathrm{~g} / \mathrm{l} \mathrm{BSA}$ ) and our artificial mucus/saliva mixture. A 0.1 part by volume of virus suspension and 0.2 parts by volume of interfering substance were mixed with 9.7 parts by volume of the hand rub product corresponding to the modified protocol to evaluate ready-to-use products at $97 \%$ according to the EN14476 standard. At the tested contact time, a tenfold dilution was made to stop the activity of the disinfectant before quantifying the remaining infectious virus using the Spearman and Karber method. Contact times of 30 and $60 \mathrm{~s}$ were assessed at $20^{\circ} \mathrm{C}$. Titer reduction is presented as the difference between the control virus titer and that after contact with the test product. This difference is given as a reduction factor including its $95 \%$ confidence interval. A reduction in virus 
titer of $\geq 4 \log 10$ (corresponding to an inactivation of $\geq 99.99 \%$ ) was regarded as evidence of sufficient virucidal activity according to EN14476 standard. The quantification limit was determined taking into account the cytotoxicity (2.5 $\log 10$ TCID50). All tests were performed in duplicate and included all EN14476 controls.

Virucidal activity according to surface test. To measure the virucidal activity on surface of a commercial disinfectant, the NF EN 16777 standard protocol was followed. The purified virus was mixed with the interfering substance (BSA $0.3 \mathrm{~g} / \mathrm{l}$, artificial saliva + epithelium mucus, BSA $3 \mathrm{~g} / \mathrm{l}+3$ $\mathrm{ml} / 1$ of sheep erythrocytes). A volume of $50 \mu \mathrm{l}$ of the mix was deposited on a previously functionalized stainless-steel disk (see previously). The inoculum was left to dry before $0.1 \mathrm{ml}$ of the disinfectant was deposited on the disk. The remaining infectious viruses were quantified by the Spearman and Karber method. The quantification limit was determined taking into account the cytotoxicity $(1.5 \log 10$ TCID50). All tests were performed in duplicate and included all EN16777 controls. 


\section{Results}

\section{Comparative surface stability of SARS-CoV-2, HCoV-229E and FCoV}

To investigate the stability of SARS-CoV-2, HCoV-229E and FCoV on stainless steel at both 7 and 25 ${ }^{\circ} \mathrm{C}$, a $50-\mu 1$ droplet of solution containing virus culture diluted in either culture media or artificial mixture (6.2, 7.1 and $6.8 \log 10$ TCID50/ml respectively for SARS-CoV-2, HCov-229E and FCoV) was pipetted onto stainless steel discs and left in an incubator at 7 or $25{ }^{\circ} \mathrm{C}$ (relative humidity: $65 \%$ ). The inoculated supports retrieved at desired time points were immediately soaked with $2 \mathrm{~mL}$ of viral culture media.

On stainless steel, SARS-CoV-2 showed greater stability at $7{ }^{\circ} \mathrm{C}$ than at $25{ }^{\circ} \mathrm{C}$, with a loss at $48 \mathrm{~h}$ post application of $1.5 \log 10 \mathrm{TCID} 50$ at $7{ }^{\circ} \mathrm{C}$ compared to $2.9 \log 10 \mathrm{TCID} 50$ at $25{ }^{\circ} \mathrm{C}$ (Figure 1A). At 72 h post application, a 3.0 Log10 TCID50 reduction was observed at $7{ }^{\circ} \mathrm{C}$ while no viable virus could be detected at $25{ }^{\circ} \mathrm{C}$. No viable virus could be measured on the surface at $7{ }^{\circ} \mathrm{C}$ at $96 \mathrm{~h}$ post application (Figure 1A). Both HCoV-229E and FCoV showed greater stability over time on stainless steel surface than SARS-CoV-2, with $\approx 1.7 \log 10$ TCID50 reduction measured $96 \mathrm{~h}$ post application at $7{ }^{\circ} \mathrm{C}$ (Figures 1B and 1C). As observed for SARS-CoV-2, the viral stability decreased at $25^{\circ} \mathrm{C}$ with only a few (HCov-229E) or no (FCoV) viable virus being detected $96 \mathrm{~h}$ post application.

\section{Effect of artificial mucus/saliva mixture on virus stability}

We then evaluated the effect of an artificial mucus/saliva mixture on the stability of the three viruses under the same temperature conditions described above. The interfering mixture induced a moderate negative impact on the stability of SARS-CoV-2 at $7{ }^{\circ} \mathrm{C}$, with $0.5,1.6$ and $1.9 \log 10$ TCID50 reductions at 30, 48 and $72 \mathrm{~h}$ post application, respectively, compared to the condition without the artificial mixture (Figure 1A). This negative impact was even stronger at $25^{\circ} \mathrm{C}$, with no viable virus measured at $48 \mathrm{~h}$ post application. Artificial mucus/saliva mixture had no significant impact on the stability of $\mathrm{HCoV}-229 \mathrm{E}$ and $\mathrm{FCoV}$ at $7{ }^{\circ} \mathrm{C}$ (Figures 1B and 1C), however, as observed for SARS- 
$\mathrm{CoV}-2$, it had a strong negative impact in both at $25^{\circ} \mathrm{C}$, with no viable virus measured at $30 \mathrm{~h}$ post application (Figures 1B and 1C).

\section{Virucidal activity according to suspension test}

In order to measure the virucidal activity of alcohol hand sanitizers, the NF EN 14476+A2 standard protocol was followed. Briefly, a volume of $0.1 \mathrm{ml}$ of interfering substance (BSA $0.3 \mathrm{~g} / \mathrm{l}$ or artificial saliva/epithelium mucus) was added to $0.2 \mathrm{ml}$ of purified virus and to $9.7 \mathrm{ml}$ of disinfectant (ready-touse product). At the tested contact times (30 and $60 \mathrm{~s}$ ), a tenfold dilution was made to stop the activity of the disinfectant before quantifying the remaining infectious virus.

Of three commercial hand rub products tested, only product 3 showed a virucidal activity at $30 \mathrm{~s} \geq 4$ $\log 10$ against SARS-CoV-2 and all other tested viruses (Figure 2A), with the mucus/saliva mixture having no impact on virucidal efficiency (Figure 2B). Moreover, when compared to the standardized clean condition, the artificial mixture had no impact on the virucidal efficiency of either product 1 or 2. Product 1 demonstrated lower virucidal efficiency compared to product 2 , with $2.3,2.75$ and 3.1 $\log 10$ reductions on SARS-CoV-2, $\mathrm{HCoV}-229 \mathrm{E}$ and FCoV titers, respectively, after a contact time of $30 \mathrm{~s}$ (Figure 2A). Of note, whereas a virucidal activity $\geq 4 \log 10$ reduction was observed after a contact time of $60 \mathrm{~s}$ with products 1 and 2 against all three coronavirus strains, product 1 demonstrated $\mathrm{a} \geq 4 \log 10$ reduction against SARS-CoV-2 in only one test after a contact time of $60 \mathrm{~s}$ (Figure 2A).

\section{Virucidal activity according to surface test}

To further investigate a potential impact of the mucus/saliva mixture on virucidal efficiency, we evaluated the virucidal activity of a commercial chemical surface disinfectant using both clean/dirty medical standardized interfering substances $(0.3 \mathrm{~g} / \mathrm{l} \mathrm{BSA}$ and $3 \mathrm{~g} / \mathrm{l} \mathrm{BSA}+3 \mathrm{ml} / \mathrm{l}$ sheep erythrocytes) and the artificial mucus/saliva mixture following EN 16777 quantitative non-porous surface tests. Stainless steel discs were inoculated with $50 \mu 1$ of a test suspension containing the standard modified vaccine Ankara virus strain (MVA) in a solution of interfering substance and let dry for $30 \mathrm{~min}$. The 
dried inoculum was covered with $100 \mu 1$ of surface disinfectant at 3 different concentrations $(1,2$ and $4 \%$ ) and maintained at $20^{\circ} \mathrm{C}$ for a contact time of 2 min. A reduction in virus titer of $\geq 4 \log 10$ was regarded as evidence of sufficient virucidal activity according to EN16777 standard.

All tested concentrations of the surface disinfectant showed virucidal activity $\geq 4 \log 10$ after 2 minutes in contact with the MVA virus, with low levels of soil content corresponding to the standardized medical "clean" condition (Figure 3). However, the use of standardized medical "dirty" interfering substances ( $3 \mathrm{~g} / \mathrm{l} \mathrm{BSA}+3 \mathrm{ml} / \mathrm{l}$ sheep erythrocytes) significantly decreased the virucidal efficiency of the product, with only the $4 \%$ concentration showing $\geq 4 \log 10$ reduction. Interestingly, the mucus/salvia mixture had a similar impact on the virucidal efficiency on stainless steel surface than that observed with the standardized "dirty" condition (Figure 3). 


\section{Discussion}

The role of contaminated surfaces as a potential significant vector for hospital-acquired viral infections has gained a whole new community-based dimension in the current COVID-19 pandemic context. In that regard, the results presented in this study demonstrate the stability of SARS-CoV-2 on smooth surfaces, with infectious virus being detected up to $48 \mathrm{~h}$ and $72 \mathrm{~h}$ post application at $25{ }^{\circ} \mathrm{C}$ and $7{ }^{\circ} \mathrm{C}$ respectively. These observations confirm recent data that SARS-CoV-2 remains infectious for several days on stainless steel surface $(10,11)$. Our data suggest a higher stability of both HCoV-229E and FCoV at both temperatures compared to SARS-CoV-2, with infectious particles being detected up to $72 \mathrm{~h}$ post application as described previously (14). As previously described for coronavirus and other respiratory viruses, SARS-CoV-2 showed greatest surface-stability at low temperature $(11,12,14)$. Numerous studies have described the role of body secretions in the observed increased stability of a large number of viral strains on environmental surfaces (15-17), as demonstrated for influenza virus in contact with respiratory mucus (18). Interestingly, the mucus/saliva mixture did not demonstrate a beneficial effect on surface survival for all tested viruses and a negative effect in SARS-CoV-2 seemed to correlate with the incubation temperature. At moderate temperatures, the mucus/saliva mixture had a strong impact on the viability of coronaviruses and quantities of virus close to the limit of detection (LOD) were detected up to $30 \mathrm{~h}$. We hypothesize that the increase in temperature from 7 to $25{ }^{\circ} \mathrm{C}$ may activate the catalytic site of antimicrobial proteins present in nasal mucus. In this sense, the most abundant airway antimicrobial factors are lysozyme (31), lactoferrin (32), and secretory leukoproteinase inhibitor (33). Lactoferrin is a multifunctional glycoprotein with a broad spectrum of antiviral activity against a wide range of viruses in vitro including enveloped viruses (34), while the antiviral spectrum of lysozyme is considerably more modest (31). Several other known antimicrobial proteins and peptides including statherin and secretory phospholipase A2 have been identified in nasal secretions and likely contribute to their antimicrobial properties (34). As observed for rhinoviruses, nasal secretions and saliva seem to reduce the ability of coronaviruses to survive on environmental surfaces at moderate temperatures (20). However, we show that a large quantity of infectious SARS$\mathrm{CoV}-2$ were still detectable on surfaces after $24 \mathrm{~h}$ post application at $25{ }^{\circ} \mathrm{C}$ in the presence of artificial 
body fluid secretions from coughing or sneezing. Laboratory simulations have demonstrated that hand-to-hand and fomite-to-hand contact are viable modes of transmission for influenza and other respiratory viruses depending how long the viral particles remain viable on hands and fomites $(9,24)$. As compared to influenza virus stability, we can hypothesize that SARS-CoV-2 remains stable on fomite as long as sufficient to contaminate hands and the risk of contaminating surfaces with SARSCoV-2 should be emphasized in guidelines for hand and surface disinfection practices.

With regards to disinfection, antiseptic hand hygiene including use of alcohol-based hand sanitizer is one of the most important measures in preventing outbreak-associated viral infections. We have shown that among the three commercially available alcohol hand sanitizers tested in our study, only one, corresponding to the ethanol-based WHO formulation, was associated with $\geq 4 \log 10$ reduction after 30 s contact with SARS-CoV-2, HCoV-229E and FCoV, while the others reached compliance with EN14476 only after $60 \mathrm{~s}$. This result confirms data from Siddharta et al. that ethanol-based WHO formulations efficiently inactivate re-emerging viral pathogens such as SARS-CoV, and MERS-CoV (35). However, the efficacy of such products is highly dependent on the technique of application, including the use of 2.4 to $3 \mathrm{ml}$ applied to the palm and rubbed all over the surfaces of both hands until they are dry, corresponding to an acceptable contact time of 25 to $30 \mathrm{~s}$ (36). As the virucidal efficiency of alcohol-based hand sanitizers is determined according to EN14476 protocol, a contact time of $30 \mathrm{~s}$ should be considered only the reference to obtain compliance according to that standard. Noteworthy, we are currently performing a comparative study involving murine hepatitis virus (betacoronavirus), MVA virus, Type 5 adenovirus and murine norovirus to define the closest surrogate for SARS-CoV-2 to enable virucidal experiments with a contact time of $30 \mathrm{~s}$ on a large panel of alcohol-based hand sanitizers.

The mucus/saliva mixture used in this study showed a strong impact on virucidal efficiency when disinfectant was applied onto a dried inoculum-contaminated surface; in contrast however, it had no impact on virucidal efficiency tested using the suspension protocol with no significant difference shown between standardized clean medical condition and mucus/saliva mixture. We hypothesize that the dilution factor of the mucus/saliva mixture used in the modified suspension protocol at $97 \%$, 
regularly used to evaluate ready-to-use hand rub products, may explain this difference. However, mucus/saliva interference had a similar impact on virucidal activity on surfaces as observed with the standardized medical dirty condition.

In summary, the democratization of the use of alcohol-based hand sanitizers from healthcare facilities to the general public as a barrier measure to prevent outbreak-associated respiratory viral infections emphasizes the importance of assessing the potential impact of interfering substances rich in protein or other biological organic matter, which are usually present in soiled hands and might significantly impact virucidal efficiency. Our results advocate for the development of standardized phase 2/step 2 testing protocols according to simulated practical conditions reflecting new "real life" needs, notably considering the impact of omnipresent secretions from coughing or sneezing on the evaluation of the virucidal activity of hand sanitizers.

\section{Acknowledgements}

LZ is the holder of a CIFRE PhD thesis grant from the Agence Nationale de Recherche Technologique (ANRT). This study was funded by INSERM REACTing (REsearch \& ACtion emergING infectious diseases), CNRS, and Mérieux research grants. The sponsors had no role in study design, collection, analysis and interpretation of data, manuscript writing, or in the decision to submit the article for publication. 
medRxiv preprint doi: https://doi.org/10.1101/2020.08.22.20180042; this version posted August 25, 2020. The copyright holder for this preprint (which was not certified by peer review) is the author/funder, who has granted medRxiv a license to display the preprint in perpetuity.

All rights reserved. No reuse allowed without permission.

\section{References}

1. Otter JA, Donskey C, Yezli S, Douthwaite S, Goldenberg SD, Weber DJ. Transmission of SARS and MERS coronaviruses and influenza virus in healthcare settings: the possible role of dry surface contamination. J Hosp Infect 2016;92:235-50.

2. Boone SA, Gerba CP. Significance of fomites in the spread of respiratory and enteric viral disease. Appl Environ Microbiol 2007;73:1687e1696.

3. Brankston G, Gitterman L, Hirji Z, Lemieux C, Gardam M. Transmission of influenza A in human beings. Lancet Infect Dis 2007;7:257e265.

4. Spicknall IH, Koopman JS, Nicas M, Pujol JM, Li S, Eisenberg JN. Informing optimal environmental influenza interventions: how the host, agent, and environment alter dominant routes of transmission. PLoS Comput Biol 2010;6:e1000969.

5. Sizun J, Yu MW, Talbot PJ. Survival of human coronaviruses 229E and OC43 in suspension and after drying on surfaces: a possible source of hospital-acquired infections. J Hosp Infect. 2000 Sep;46(1):55-60. doi: 10.1053/jhin.2000.0795.

6. Sattar, S. 2004. Microbicides and the environmental control of nosocomial viral infections. J. Hosp. Infect. 56(Suppl. 2):S64-S69.

7. Xiao S, Li Y, Wong TW, Hui DSC. Role of fomites in SARS transmission during the largest hospital outbreak in Hong Kong. PLoS One 2017;12:e0181558.

8. Boone SA, Gerba CP. The occurrence of influenza 1 virus on household and day care center fomites. J Infect. 2005 Aug;51(2):103-9. doi: 10.1016/j.jinf.2004.09.011. Epub 2004 Nov 5.

9. Ansari SA, Springthorpe VS, Sattar SA, Rivard S, Rahman M. Potential role of hands in the spread of respiratory viral infections: studies with human parainfluenza virus 3 and rhinovirus 14 . J Clin Microbiol 1991;29:2115e9.

10. Neeltje van Doremalen1, Trenton Bushmaker, Dylan H. Morris, Myndi G. Holbrook, Amandine Gamble, Brandi N. Williamson, Azaibi Tamin, Jennifer L. Harcourt, Natalie J. Thornburg, Susan I. Gerber, James O. Lloyd-Smith, Emmie de Wit, Vincent J. Munster. Aerosol and surface stability of HCoV-19 (SARS-CoV-6 2) compared to SARS-CoV-1. N Engl J Med. 2020 Apr 16;382(16):15641567.

11. Alex Chin, Julie Chu, Mahen Perera, Kenrie Hui, Hui-Ling Yen, Michael Chan, Malik Peiris, Leo Poon. Stability of SARS-CoV-2 in different environmental conditions. The Lancet Microbe doi: $10.1016 /$ S2666-5247(20)30003-3. 
medRxiv preprint doi: https://doi.org/10.1101/2020.08.22.20180042; this version posted August 25, 2020. The copyright holder for this preprint (which was not certified by peer review) is the author/funder, who has granted medRxiv a license to display the preprint in perpetuity.

All rights reserved. No reuse allowed without permission.

12. Lisa M Casanova, Soyoung Jeon, William A Rutala, David J Weber, Mark D Sobsey. Effects of Air Temperature and Relative Humidity on Coronavirus Survival on Surfaces. Appl Environ Microbiol. 2010 May;76(9):2712-7.

13. van Doremalen N, Bushmaker T, Munster VJ. Stability of Middle East respiratory syndrome coronavirus (MERS-CoV) under different environmental conditions. Euro Surveill. 2013 Sep $19 ; 18(38)$.

14. Chan KH1, Peiris JS, Lam SY, Poon LL, Yuen KY, Seto WH. The Effects of Temperature and Relative Humidity on the Viability of the SARS Coronavirus. Adv Virol. 2011;2011:734690.

15. Karen A. McCaustland, Walter W. Bond, Daniel W. Bradley, James W. Ebert, James E. Maynard. Survival of Hepatitis A Virus in Feces After Drying and Storage for 1 Month. Journal of clinical microbiology, Nov. 1982, P. 957-958.

16. K. Moe and Jane A. Shirley. The Effects of Relative humidity and Temperature on the Survival of Human Rotavirus in Faeces. 1982 Archives of Virology 72, 179--186.

17. Van Bueren, J., Simpson, R. A., Jacobs, P., \& Cookson, B. D. Survival of human immunodeficiency virus in suspension and dried onto surfaces.1994. Journal of Clinical Microbiology, 32(2), 571-574.

18. Thomas Y1, Vogel G, Wunderli W, Suter P, Witschi M, Koch D, Tapparel C, Kaiser L. Survival of influenza virus on banknotes. Appl Environ Microbiol. 2008 May;74(10):3002-7.

19. Parker, E. R., W. B. Dunham, and W. J. MacNeal. 1944. Resistance of the Melbourne strain of influenza virus to desiccation. J. Lab. Clin. Med. 29:37-42.

20. S A Sattar, Y G Karim, V S Springthorpe, C M Johnson-Lussenburg. Survival of human rhinovirus type 14 dried onto nonporous inanimate surfaces: effect of relative humidity and suspending medium. Can J Microbiol. 1987 Sep;33(9):802-6.

21. Nicolas de Lamballerie C, Pizzorno A, Dubois J, Julien T, Padey B, Bouveret M, Traversier A, Legras-Lachuer C, Lina B, Boivin G, Terrier O, Rosa-Calatrava M. Characterization of cellular transcriptomic signatures induced by different respiratory viruses in human reconstituted airway epithelia. Sci Rep. 2019 Aug 7;9(1):11493. doi: 10.1038/s41598-019-48013-7.

22. ASTM E2721 (2016). Standard Practice for Evaluation of Effectiveness of Decontamination Procedures for Surfaces When Challenged with Droplets Containing Human Pathogenic Viruses.

23. NF EN17122 (2019) . Chemical disinfectants and antiseptics - Quantitative non-porous surface test for the evaluation of virucidal activity of chemical disinfectants and antiseptics used in the veterinary area — Test method and requirements — Phase2, step2.

24. Bean B, Moore BM, Sterner B, Peterson LR, Gerding DN, Balfour HH. Survival of influenza viruses an environmental surfaces. J Infect Dis 1982;146:47e51. 
medRxiv preprint doi: https://doi.org/10.1101/2020.08.22.20180042; this version posted August 25, 2020. The copyright holder for this preprint (which was not certified by peer review) is the author/funder, who has granted medRxiv a license to display the preprint in perpetuity.

All rights reserved. No reuse allowed without permission.

25. Xiao S, Li Y, Sung M, Wei J, Yang Z. A study of the probable transmission routes of MERS-CoV during the first hospital outbreak in the Republic of Korea. Indoor Air. 2018;28:51-63.

26. Xiao S, Li Y, Lei H, et al. Characterizing dynamic transmission of contaminants on a surface touch network. Build Environ. 2018;129:107-116.

27. Paula A. Araújo, Madalena Lemos, Filipe Mergulhão, Luís Melo, Manuel Simões. The Influence of Interfering Substances on the Antimicrobial Activity of Selected Quaternary Ammonium Compounds. Int J Food Sci. 2013; 2013: 237581.

28. R.J.W. Lambert and M.D. Johnston. The effect of interfering substances on the disinfection process: a mathematical model. Journal of Applied Microbiology 2001, 91, 548-555.

29. NF EN16777 (2018). Chemical disinfectants and antiseptics - Quantitative non-porous surface test without mechanical action for the evaluation of virucidal activity of chemical disinfectants used in the medical area - Test method and requirements (phase 2/step 2).

30. NF EN14476+A2 (2019). Chemical disinfectants and antiseptics - Quantitative suspension test for the evaluation of virucidal activity in the medical area - Test method and requirements (Phase 2/Step $1)$.

31. Harbitz, O., A. O. Jenssen, and O. Smidsrod. 1984. Lysozyme and lactoferrin in sputum from patients with chronic obstructive lung disease. Eur. J. Respir. Dis. 65:512-520.

32. Arnold, R. R., M. Brewer, and J. J. Gauthier. 1980. Bactericidal activity of human lactoferrin: sensitivity of a variety of microorganisms. Infect. Immun. 28:893-898.

33. Hiemstra, P. S., R. J. Maassen, J. Stolk, R. Heinzel-Wieland, G. J. Steffens, and J. H. Dijkman. 1996. Antibacterial activity of antileukoprotease. Infect. Immun. 64:4520-4524.

34. Villa TG, Feijoo-Siota L, Rama JL, Ageitos JM. Antivirals against animal viruses. Biochem Pharmacol. 2017;133:97-116.

35. Siddharta A, Pfaender S, Vielle NJ et al. Virucidal Activity of World Health OrganizationRecommended Formulations Against Enveloped Viruses, Including Zika, Ebola, and Emerging Coronaviruses. J Infect Dis 2017; 215: 902-6.

36. Kampf G. Efficacity of ethanol against viruses in hand disinfection. J Hosp Infect. 2018 Apr;98(4):331-338. 
medRxiv preprint doi: https://doi.org/10.1101/2020.08.22.20180042; this version posted August 25, 2020. The copyright holder for this preprint (which was not certified by peer review) is the author/funder, who has granted medRxiv a license to display the preprint in perpetuity.

All rights reserved. No reuse allowed without permission. 


\section{Figure captions}
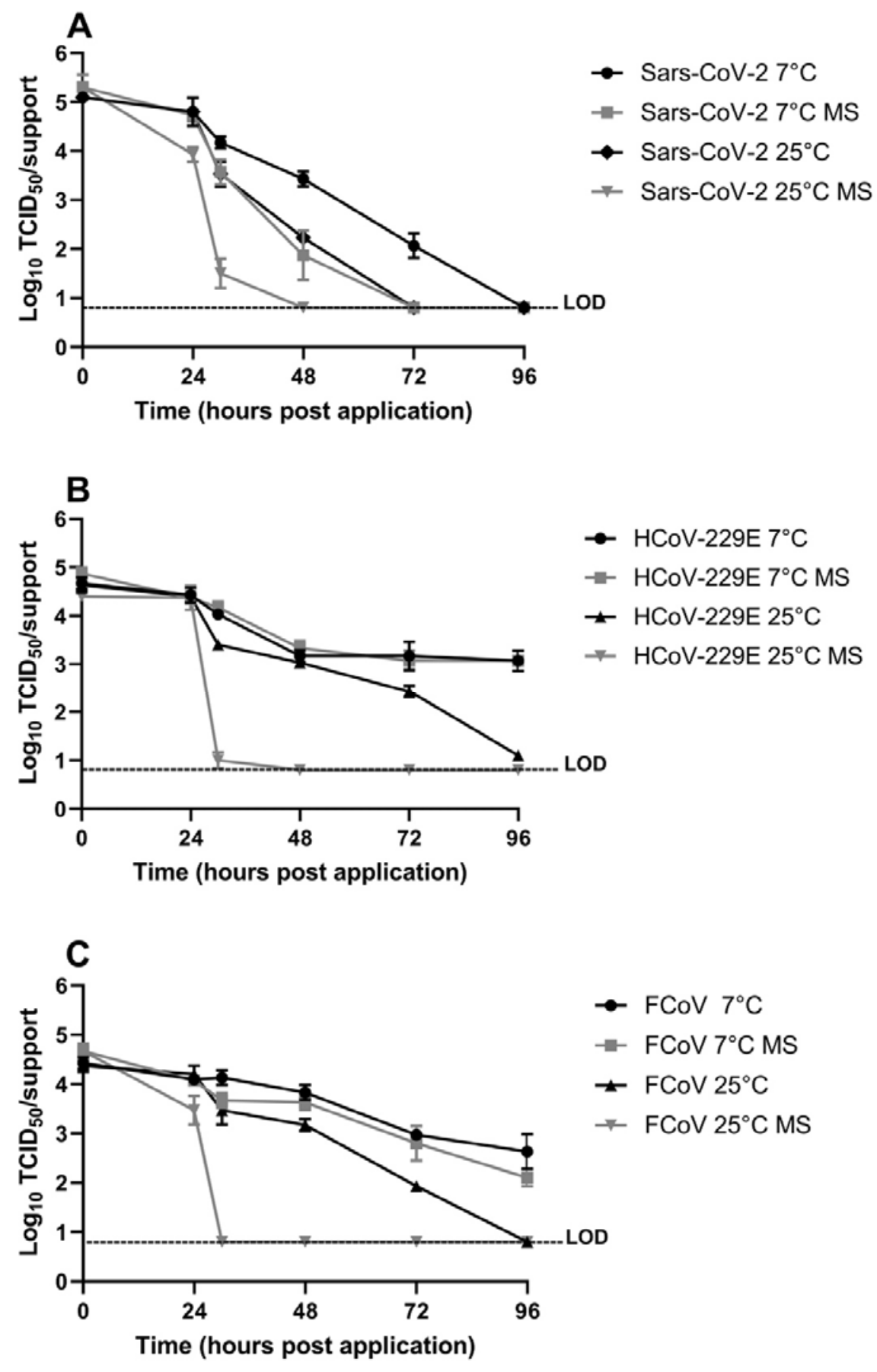

Figure 1. Stability of SARS-CoV-2 (A), HCov-229E (B) and FCoV (C) on stainless steel. Viral suspensions diluted in either culture media or artificial mucus/saliva mixture (6.2, 7.1 and $6.8 \log 10 \mathrm{TCID} 50 / \mathrm{mL}$ respectively for SARS-CoV-2, HCov-229E and FCoV) were deposited onto stainless steel discs and left in an incubator at 7 or $25{ }^{\circ} \mathrm{C}$ (relative humidity: $65 \%$ ). The inoculated supports retrieved at desired time points were immediately soaked with $2 \mathrm{ml}$ of viral culture media. The limit of detection (LOD) for all experiments was $0.8 \log 10$ TCID50/support. 

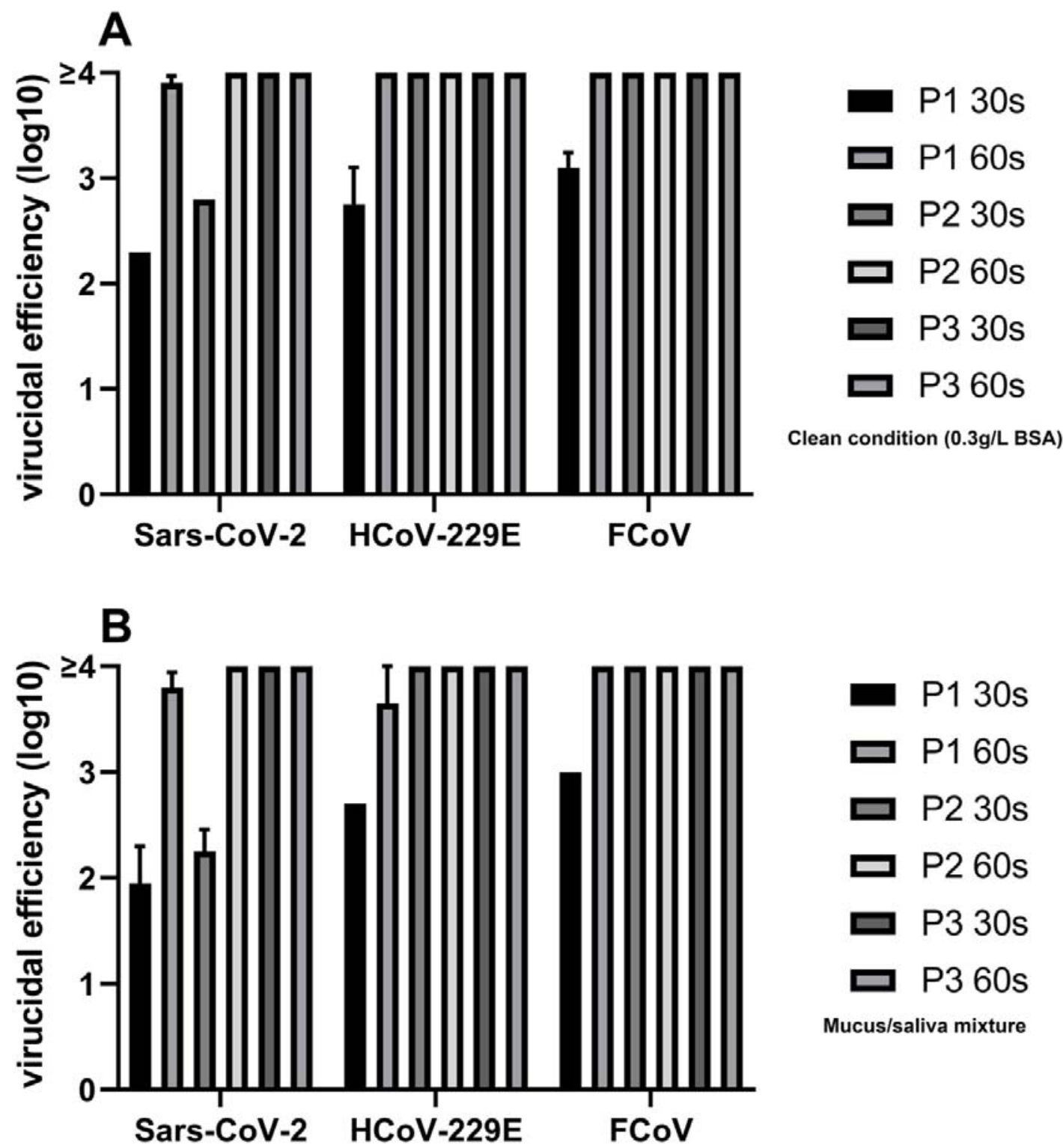

Figure 2. Virucidal activity of three commercial hand rub sanitizer products against SARS-CoV-2, HCoV229E and FCoV. Virucidal activity was determined using the quantitative suspension test according to EN 14476, comparing the standardized interfering substance ("clean" condition, $0.3 \mathrm{~g} / \mathrm{l} \mathrm{BSA} \mathrm{(A)} \mathrm{with} \mathrm{the} \mathrm{artificial}$ mucus/saliva mixture (B). The remaining infectious viruses were quantified by the Spearman and Karber method. The quantification limit was determined taking into account the cytotoxicity of the products $(2.5 \log 10$ TCID50). 


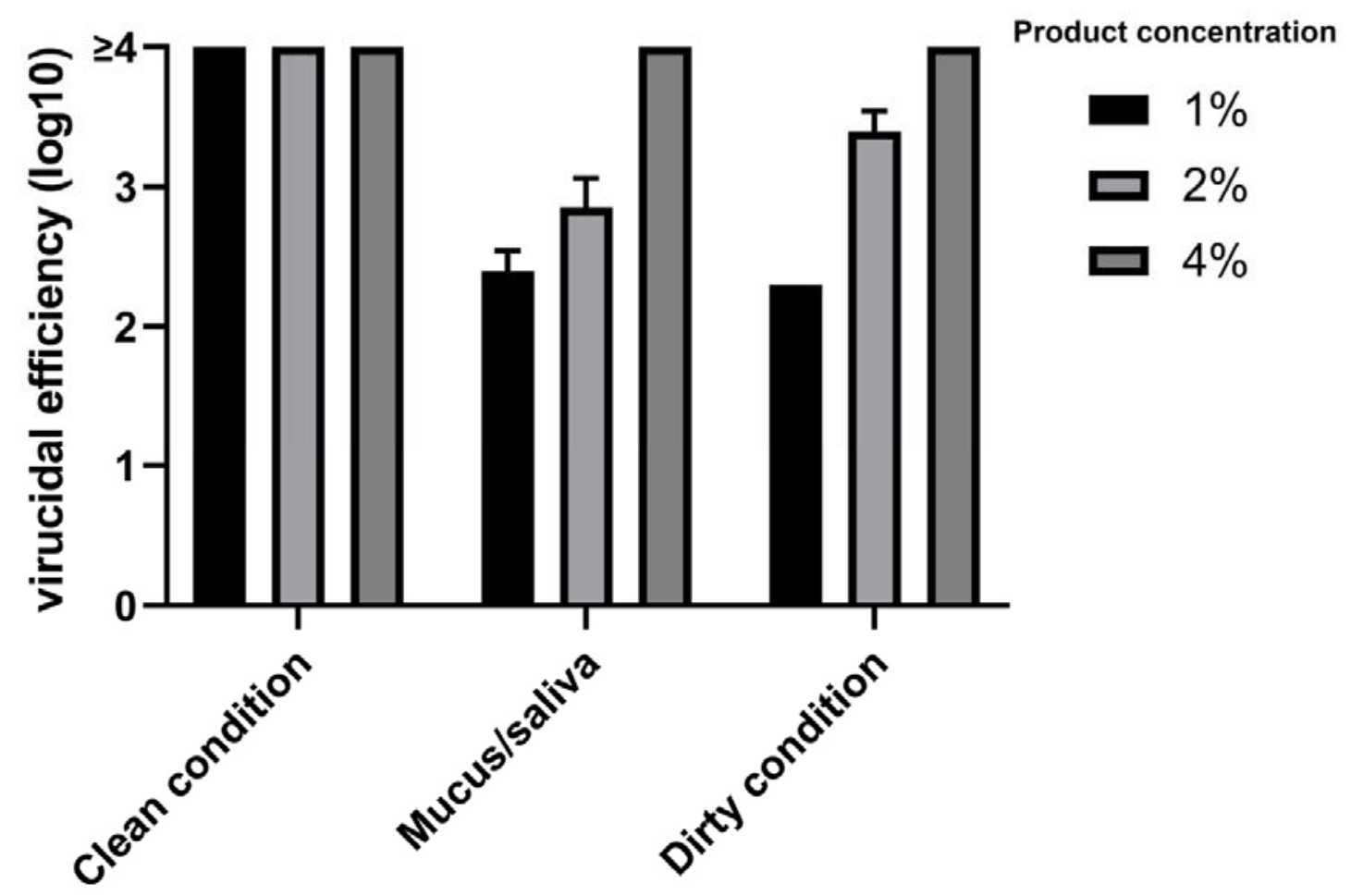

Figure 3. Virucidal activity of a commercial surface disinfectant. The purified virus was mixed with the interfering substance ("clean" condition: BSA $0.3 \mathrm{~g} /$, artificial saliva + epithelium mucus, "dirty" condition: BSA $3 \mathrm{~g} / \mathrm{l}+3 \mathrm{ml} / \mathrm{l}$ of sheep erythrocytes). A volume of $50 \mu \mathrm{l}$ of the mix was deposited on a previously functionalized stainless-steel disk (see previously). The inoculum was left to dry before $0.1 \mathrm{ml}$ of the disinfectant (1, 2 and $4 \%$ concentrations) was deposited on the disk. The remaining infectious viruses were quantified by the Spearman and Karber method. The quantification limit was determined taking into account the cytotoxicity of the product (1.5 $\log 10$ TCID50). 